\title{
Peculiar Tonsil-like Structure near Vagina of the Laboratory Shrew, Suncus murinus
}

\author{
By

\section{Kazuyoshi SAKAI ${ }^{1}$, Hideki IMADA ${ }^{2}$, Masanori SHINZATO ${ }^{3}$, Kazuhiro NISHII ${ }^{1}$, Ei-ichi MIYACHI ${ }^{2}$, Yoshimitsu KATOH ${ }^{1}$, and Kouji YAMADA ${ }^{1}$}

\author{
${ }^{1}$ Department of Anatomy, School of Health Sciences \\ ${ }^{2}$ Department of Physiology, School of Medicine \\ ${ }^{3}$ Department of Pathology, School of Health Sciences Fujita Health University, \\ 1-98. Dengakugakubo, Kutsukake-cho, Toyoake, Aichi, Japan
}

-Received for Publication, November 22, $2012-$

\author{
Key Words: Vaginal tonsil, Lymph tissue, Laboratory shrew
}

\begin{abstract}
Summary: After finding tonsil-like structures near the entrance of vagina of a laboratory shrew (Suncus murinus), which we subsequently designated as vaginal tonsils, we performed detailed immunohistochemical and developmental studies. The location of $T$ and $B$ cells in the vaginal tonsils differed from that in the palatine tonsils or that in the lymphoid nodes of other animals. The boundary between the germinal center region and the region encompassing follicular interfollicular tissue was not clear. B cells were widely distributed and very dense in the parenchyma, but they were scattered in the epithelial area (B cells were present in around $\mathbf{9 0 \%}$ of the vaginal tonsil tissue). In contrast, $T$ cells were scattered in the parenchyma and in the epithelial area ( $T$ cells were present in around $10 \%$ of the vaginal tonsil tissue). B cells were more prominent than $T$ cells throughout the development of these structures and the epithelium was invaded by many immigrating cells. The size of the vaginal tonsils changed during postnatal development. Vaginal tonsils are structurally similar to other tonsils, and they may function to protect the vagina from infection.
\end{abstract}

\section{Introduction}

The tonsils of lymphatic tissues are defined as apparent lymph nodules that lie under well-developed crypt epithelium and exhibit prominent immunocyte infiltration and capsular demarcation (Fioretti, 1961). The gastrointestinal and respiratory tracts are in frequent contact with a wide variety of antigenic material. Anatomically well-organized lymphoid tissues that are in intimate contact with epithelia of the gastrointestinal and respiratory tract constitute mucosa-associated lymphoid tissue (MALT). Therefore, lymphoid tissues located in organs like the tonsils are believed to form the first immunological barrier against pathogenic antigens.

While the tonsils of many mammalian species have been studied, those of mammalian insectivores have not. The laboratory shrew is a small insectivore and of special interest with respect to the evolution of mammals because they are a direct ancestor of humans and are closer relatives of primates than are mice, rats or guinea pigs (Lin et al., 1985, Ishiguro et al., 1989, Tada et al., 1988). These shrews have a pair of palatine tonsils in the fauces (Kimura and Tohya, 1989). In addition, we identified tonsillar structures near the ostium urogenitoanale in the laboratory shrew (Sakai et al., 2002, Sakai and Isomura, 2004). One feature of the laboratory shrew is that the rectum, urethra and vagina are not independent structures; conversely, they all share a large common cavity called the ostium urogenitoanale (Fig. 1). Due to the fact that the ostium urogenitoanale retains its shape from the embryo stage, it is of particular interest in relation to the development of MALT.

We found peculiar newly recognized tonsil-like structures around the vagina in the ostium urogenitoanale that we named vaginal tonsils. Here, we describe the histological structure of these tonsils and the localization of T- and B-cells within them; we used both immunohistochemical techniques and morphological analyses to assess changes in the size and structure of these organs in the days after birth. 


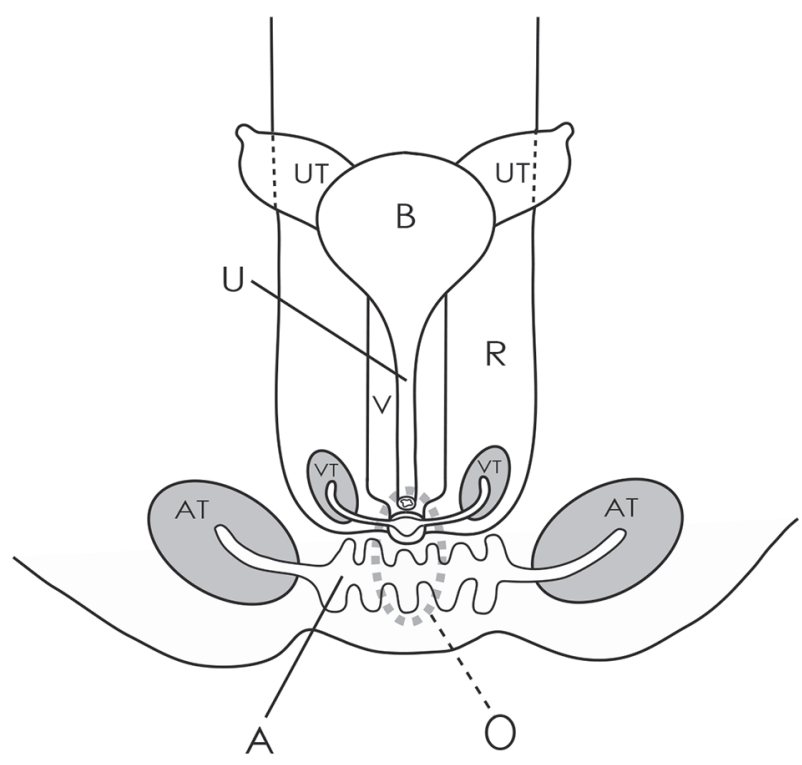

Fig. 1. Schematic drawing of the anal tonsil (AT) and vaginal tonsil (VT) associated to the ostium urogenitoanale (O), anus (A), vagina $(\mathrm{V})$ in the laboratory shrew. Ventral view. B: urinary bladder, R: rectum, U: urethra, UT: uterus.

\section{Materials and Methods}

\section{Animals}

Laboratory shrews (Suncus murinus) of females were used on Days 10, 20, 30, 40, 50, 60, 70, 80, 90, 100, $120,140,200,240,280,300,400,500$. They were bred in air-conditioned room (room temperature: $24 \pm 1^{\circ} \mathrm{C}$, humidity: $55 \pm 5 \%$ ) in the Education and Research Center of Animal Models for Human Disease at Fujita Health University. All animals were handled in accordance with the National Institute of Health "Guide for the care and use of laboratory animals" and the experimental protocol was approved by the Education and Research Center of Animal Model for Human Disease of Fujita Health University, School of Medicine (Admission No. C0101).

\section{Antisera}

Specific monoclonal antibodies against shrew B-cells and T-cells, respectively, ST1 and ST4, were provided by Dr. Tohya and Dr. Kimura, of Kansai University of Health Sciences. The specificity of each serum is described elsewhere (Kimura et al., 1996; Tohya and Kimura, 1994).

\section{Tissue preparation}

The animals were anesthetized by intraperitoneal injection of sodium pentobarbital $(60 \mathrm{mg} / \mathrm{kg})$, and were perfused through the ascending aorta with $0.15 \mathrm{M} \mathrm{NaCl}$ in $0.05 \mathrm{M}$ sodium phosphate buffer (PBS, $\mathrm{pH}$ 7.4), followed by ice-chilled $4 \%$ paraformaldehyde in $0.1 \mathrm{M}$ sodium phosphate buffer (PB, pH 7.4). After sufficient fixation, the caudal half of each animal was removed with a scissors. All the tissues around the ostium urogenitoanale except the skeletal elements of the pelvis were then carefully removed with a scissors and forceps under a dissecting microscope and were immersed in the same fixative for 24 hrs. The tissues were rinsed in $0.1 \mathrm{M} \mathrm{PB}$ containing 10, 20, and $30 \%$ sucrose for 3 days. Frozen serial sections, $10 \mu \mathrm{m}$ thick, were then made using a cryostat and were divided into two groups for $\mathrm{HE}$ and immunohistochemical staining followed by light microscopic analysis.

Immunohistochemistry for examination by light microscopy

For immunoperoxidase labeling, endogenous peroxidase activity was blocked by incubation in $0.5 \% \mathrm{H}_{2} \mathrm{O}_{2}$ in methanol for $30 \mathrm{~min}$, The sections were then blocked after the incubation with $2 \%$ normal goat serum containing PBS for 30 min, following which the sections were incubated with ST1 (diluted in 1:500) or ST4 antibody (diluted in 1:700) at room temperature for $2 \mathrm{hrs}$. After washing with PBS, the sections were incubated with a peroxidaseconjugated goat anti-mouse IgG (Vectastain Elite ABC kit, Vector Laboratories, Burlingame, CA, Hsu SM et al. 1981) followed by incubation with the enzyme substrate, 0.04\% 3,3'-diaminobenzidine tetrahydrochloride (DAB; Merck KGaA, Darmstadt, Germany) containing 0.01\% $\mathrm{H}_{2} \mathrm{O}_{2}$, at room temperature for $10-15 \mathrm{~min}$. The sections were washed with running water, dehydrated in a graded series of ethanol and xylene, and were then mounted with Malinol (Muto Pure Chemicals, Tokyo, Japan). Peroxidase-labeled specimens were observed using a BX51 microscope (Olympus, Tokyo, Japan).

\section{Electron microscopy}

For transmission electron microscopy (TEM), the animals were perfused with an ice-chilled solution containing $2.5 \%$ glutaraldehyde and $2.0 \%$ paraformaldehyde through the ascending aorta. After dissection of the ostium urogenitoanale, anal tract tissue containing a pair of tonsils was removed and immersed in the same fixative for $8 \mathrm{hrs}$ at $4^{\circ} \mathrm{C}$. After washing with $0.1 \mathrm{M} \mathrm{PB}$ (pH 7.4), the samples were postfixed with $2.0 \%$ osmium tetroxide in $\mathrm{PB}$ (pH 7.4) for 1 hour at $4^{\circ} \mathrm{C}$, dehydrated with graded ethanol concentrations, and embedded in Epon 812 (TAAB, Berks, England). Ultrasections that were made using an ultramicrotome (Leicaultracut OmU4, Leica, Wetzlar, Germany) were stained with uranyl acetate and lead citrate, and were then examined using a JEM 1010 (JEOL, Tokyo, Japan) electron microscope at an accelerating voltage of $80 \mathrm{kV}$.

\section{Quantitative Evaluation}

The area of the vaginal tonsil was measured in nine laboratory shrews of female, aged 40-400 days after birth weeks. We made serial transversely cut sections of the anal tonsil from the rostral top to the caudal end. The sections were stained by HE staining. The area of the vaginal tonsil 
of these stained sections was quantified using the image analyzing software WINROOF (Mitani Corporation, Fukui, Japan) combined with photomicroscopy.

\section{Results}

\section{Structure of vaginal tonsils}

The vaginal tonsils were located in the ostium urogenitoanale near the vaginal opening, and consisted of a great number of lymphocytes under the epithelium. They were positioned bilaterally next to the walls of the vagina (Fig. 2A, B, C and D), which were densely packed by numerous lymphoid cells without germinal center (Fig. 2A, B and C).

Several lymphoid cells had invaded the epithelium (Fig. 2E arrows). The vaginal tonsils first appeared at 40 days after birth (Fig. 2A). On days 80 and 100 after birth, they were situated as they had been 40 days after birth, but they had grown much larger (Fig. 2B, C). After day 240, they tended to be smaller than they were at around 80-100 days after birth (Fig. 2D, F). After day 400, they had either become very small in size or disappeared.

In transmission electron micrographs, the surface tissue of these tonsils appeared to be composed of 3-4 layers of stratified cuboidal epithelial cells, and the epithelium seemed to contain a small number of invading immune cells (Fig. 3A). The surface of the epithelium seemed to contain enlarged immune cells that caused peeling of neighboring epithelial cells (Fig. 3B). The apical surface of each squamous cell had microridges characteristic of tonsillar epithelial cells (Fig. 3C, D and E). The squamous cells were connected to one another via tight junctions, and each cell contained several prominent mitochondria (Fig. 3D arrows). The epithelium was characterized by massive infiltration of immigrating cells, which were neutrophils (Fig. 3F), lymphocytes (Fig. 3G, H), macrophages or plasma cells (Fig. 3I). Some of these invading cells formed discreet cellular units within the epithelium and others invaded into the middle of the epithelium as lone cells.

Distribution T cells and B cells in tissues within the vaginal tonsils

The ST1 and ST4 monoclonal antibodies (mAbs) which recognize B cells or T cells, respectively - were used to label vaginal tonsil tissue sections from the house shrew that were detected by immunoperoxidase staining.

Before the tenth day after birth, a pair of deep dorsal crypts that comprised three or four layers of epithelial cells was evident at the dorsal boundary near opening of the vagina; however, few lymphoid cells were apparent around these crypts.

Between day 10 and day 20 after birth, lymphocytes accumulated in the subepithelial layer under the basement membrane of the crypt and began to form a lymph nodule; at this time, the vaginal tonsils contained only ST1 positive cells.

Between days 40 and 100, ST1 positive cells were widely distributed and very dense in the parenchyma (Fig. 4A). They were scattered throughout the epithelium (Fig. $4 \mathrm{~B})$, but more densely gathered in the subepithelial layer and the parenchyma (Fig. 4C).

In the follicular area, which was considered to be the B cells area, ST4-positive cells were scattered (Fig. 4D). ST4-positive cells were also observed in the epithelium (Fig. 4E arrows). In particular, many ST4-positive cells were located in and around the capillaries (Fig. 4F arrows).

Following the 240th day after birth, the vaginal tonsils were generally smaller than they had been the day after birth, but the distribution of ST1-positive and ST4-positive cells was similar to that on day 80 (Fig. 4G, I). However, ST1-positive or ST4-positive cells were not present in the epithelium (Fig. 4H, J).

The vaginal tonsils appeared around 40 days after birth and increased in size over time, peaking at $0.025 \mathrm{~mm}^{3}$ between 100-120 days after birth; after that, the size began to decrease (Fig. 5). Between $8.8 \%$ and $19.0 \%$ of the area of the tonsils was occupied by $\mathrm{T}$ cells, and between $76.2 \%$ and $91.2 \%$ was occupied by B cells (Table 1 ).

\section{Discussion}

We examined the histological features of the vaginal tonsils of the laboratory shrew and the localization of lymphocytes within these tonsils; we used antibodies specific for the $\mathrm{T}$ cells or $\mathrm{B}$ cells of the laboratory shrew because commercially available antibodies did not react to the shrew lymphocytes. The antibodies against $\mathrm{T}$ cells or B cells determinants used in this study were previously shown to react to molecules associated with house shrew lymphocytes (Kimura et al., 1996, Tohya and Kimura, 1994).

Concerning the area of distribution of $\mathrm{T}$ and $\mathrm{B}$ cells in the vaginal tonsils, nearly the entire tonsil area was occupied by B cells, but T cells were more scattered and occupied less of the area. Some investigators have asserted that the populations of $\mathrm{T}$ and $\mathrm{B}$ cells are nearly equal in number in cell suspensions generated from human palatine tonsils. In humans, The distribution rate of $\mathrm{T}$ and $\mathrm{B}$ cells amounts to $48 \%$ and $43 \%$, respectively, as assessed by flow cytometry (Uchida, 1983), whereas in pigs, the $\mathrm{B}$ and $\mathrm{T}$ cell populations of the palatine tonsil are about $25 \%$ and $60 \%$, respectively, (Boeker, 1999). Generally, the number of $T$ cells in the palatine tonsils of a mammal is greater than that of $\mathrm{B}$ cells. In the palatine tonsils, $\mathrm{T}$ cells are distributed mainly in the interfollicular area, while B cells are in the follicular area (Hoffmann-Fezer et al., 1981, Greaves et al., 1974, Brochier et al., 1978). However, the distribution of lymphocytes within the vaginal tonsils of the laboratory shrew differed from that within the palatine tonsils 

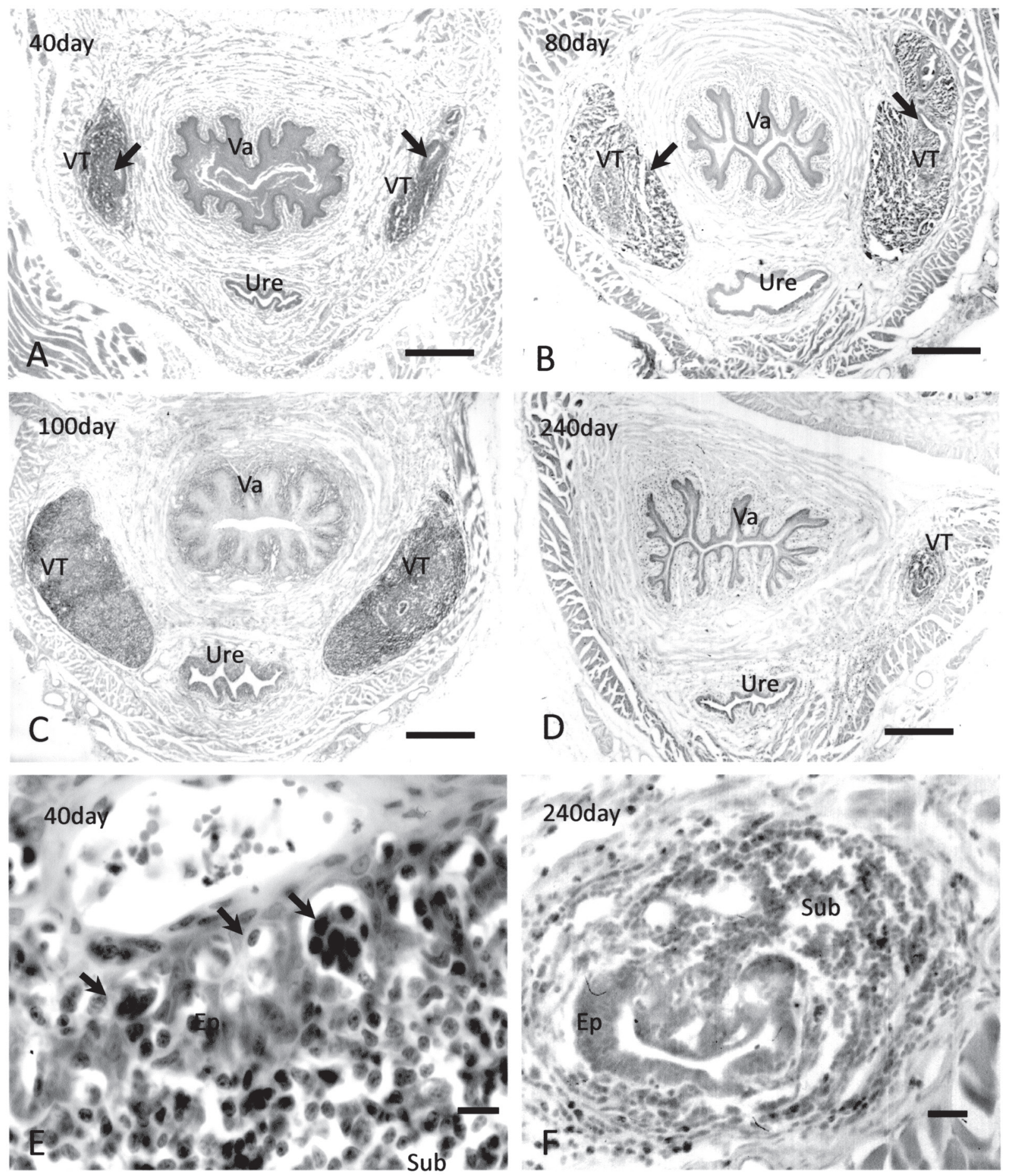

Fig. 2. Different stages in the development of vaginal tonsil as demonstrated in a transverse section around vagina stained with hematoxylin-eosin. A. Postnatal day 40. Lymphocytes were gathering around the crypt epithelium (arrows) beside vagina. VT: vaginal tonsil. Ure: Urethra. Va: Vagina. Arrow: Epithelium. Bar: $500 \mu \mathrm{m}$. B. Postnatal day 80. The size is much larger compare to 40 days. Arrows: Epithelium in the vaginal tonsil. VT: vaginal tonsil. Ure: Urethra. Va: Vagina. Bar: $500 \mu \mathrm{m}$. C. Postnatal day 100. The largest size accumulation of lymphoid cells is seen beside the vagina. VT: vaginal tonsil. Ure: Urethra. Va: Vagina. Bar: $500 \mu \mathrm{m}$. D. Postnatal day 240. The size of lymphoid tissue is much smaller than that of 100 day. VT: vaginal tonsil. Ure: Urethra. Va: Vagina. Bar: $500 \mu \mathrm{m}$. E. Closer view of epithelium in figure 1A. Lymphocytes were existed in the epithelium (arrows). Ep: Epithelium. Sub: Subepithelial layer. Bar: $10 \mu \mathrm{m}$. F. Closer view of epithelium in figure 1D. Ep: Epithelium. Sub: Subepithelial layer. The size of 240 day is much smaller than that of 100 day. Few cells infiltrated into the epithelium. Bar: $100 \mu \mathrm{m}$. 

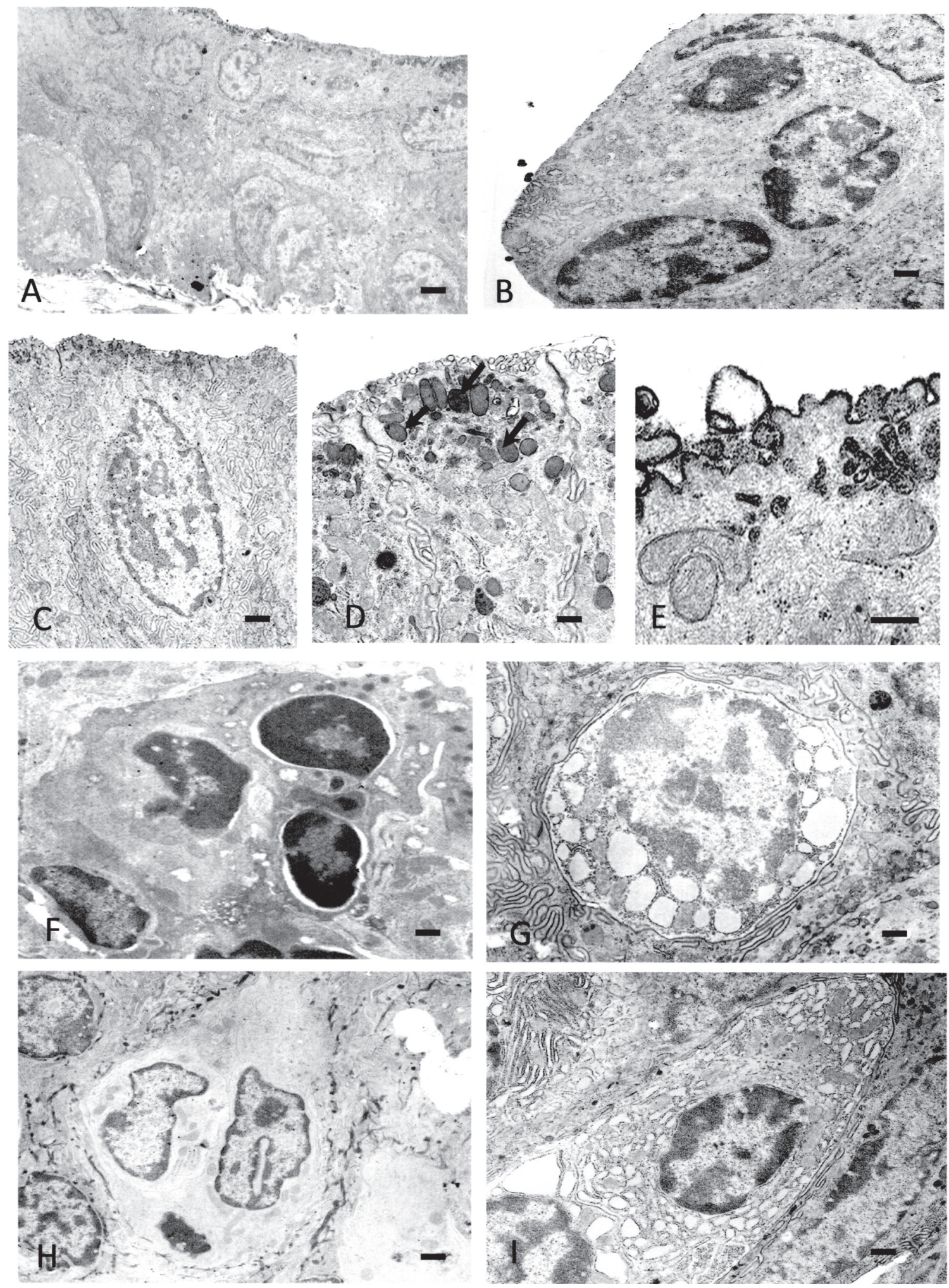

Fig. 3. Electron micrographs of the vaginal tonsillar crypt epithelium. A: The epithelium consisted of cuboidal squamous three or four cells layer. Bar: $2 \mu \mathrm{m}$. B. A peeled epithelial cell can be seen on the surface of the epithelium. Bar: $1 \mu \mathrm{m}$. C. The surface of the epithelium was cuboidal in shape. Bar: $1 \mu \mathrm{m}$. D. Near the surface cell membrane a lot of mitcondria like organelles (arrows) were observed. Bar: $0.5 \mu \mathrm{m}$. E. The surface side of the epithelial cell had microvilli and glycogen granules at several part of the epithelium. Bar: $0.1 \mu \mathrm{m}$. F. A neutrophil was invading in the surface. $1 \mu \mathrm{m}$. G. A lymphocyte with well developed reticulum was invading in the surface. $1 \mu \mathrm{m}$. H. Immatured lymphocytes were also observed in the epithelium. Bar: $1 \mu \mathrm{m}$. I. A plasma cell with well developed ER existed in the epithelium. Bar: $1 \mu \mathrm{m}$. 

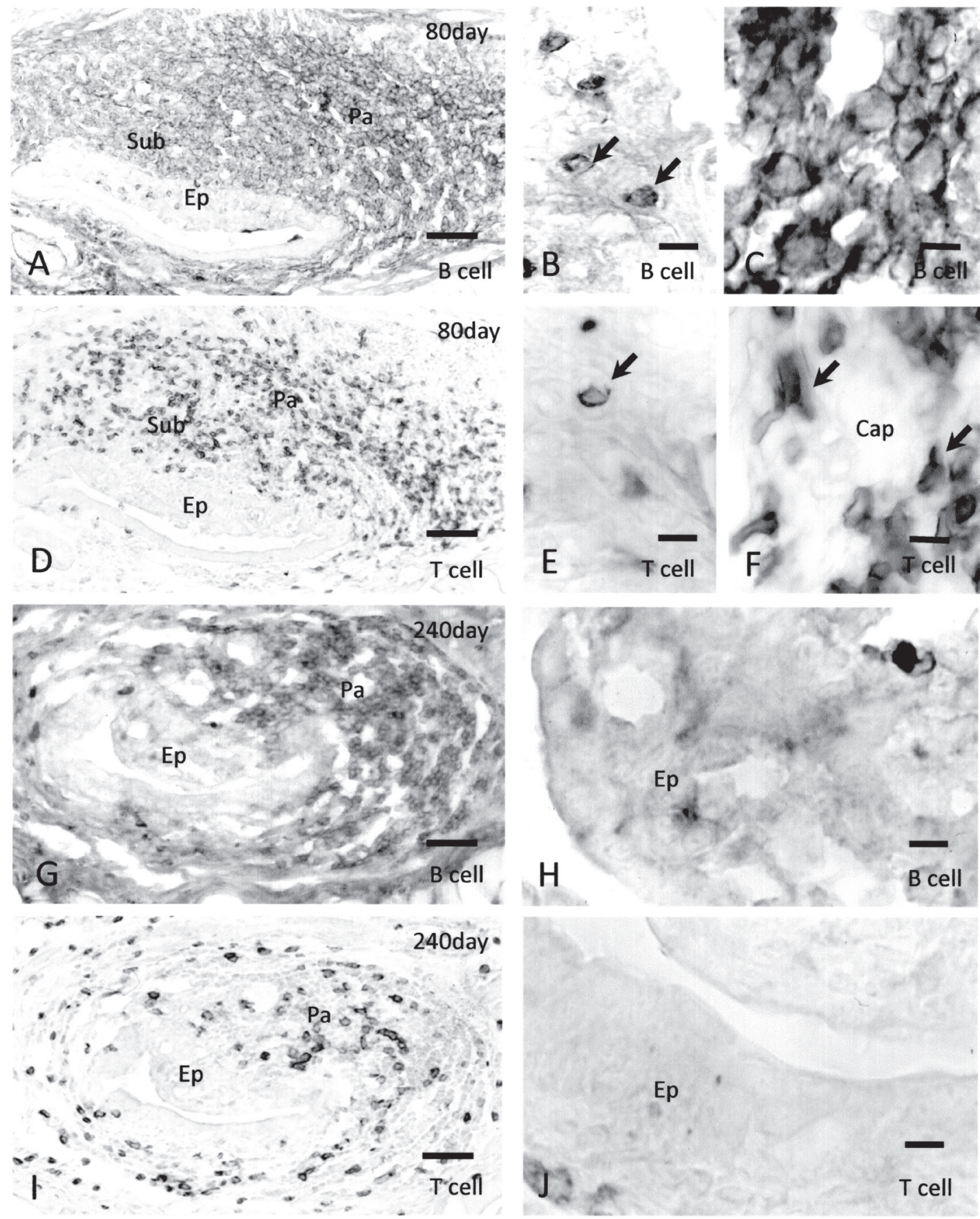

Fig. 4. T cells and B cells localization in the vaginal tonsil. A. Immunoperoxidase staining of a vaginal tonsil section using the ST1 antibody on 80 day after birth. ST1-positive cells were predominantly distributed in the parenchyma of the tonsil. Sub: Subepithelial area. Pa: Parenchyma. Ep: Epithelium. Bar: $100 \mu \mathrm{m}$. B. Magnification of epithelium in the area in Fig. 3A. Several ST1 positive cells were found in the epithelium (arrows). Ep: Epithelium. Bar: $10 \mu \mathrm{m}$. C. Magnification of the parenchyma area in Fig. 3A. A lot of ST1 positive cells filled with in the parenchyma Bar: $10 \mu \mathrm{m}$. D. Immunoperoxidase staining of a vaginal tonsil section using the ST4 antibody. ST4-positive cells were scattered in the parenchyma of the tonsil. Sub: Subepithelial area. Pa: Parenchyma. Ep: Epithelium. Bar: $100 \mu \mathrm{m}$. E. Magnification of the epithelium in Fig. 3D.ST4 positive cells were scattered in the parenchyma (arrow). Ep: Epithelium. Bar: $10 \mu \mathrm{m}$. F. Magnification of the parenchyma area in Fig. 3D. Several ST4 positive cells were found around the capillary (arrows). Cap: capillary Bar: $10 \mu \mathrm{m}$. G. Immunoperoxidase staining of a vaginal tonsil section using the ST1 antibody on 240 day after birth. The distribution of ST1 positive cells were same compare to the 80 days section. However, the size of this period is smaller than that of 80 day. Bar: $50 \mu \mathrm{m}$. H. Magnification of epithelium in the area in Fig. 3G. Infiltration of ST1 positive cells were not observed. Bar: $10 \mu \mathrm{m}$. I. Immunoperoxidase staining of a vaginal tonsil section using the ST4 antibody. The distribution of ST1 positive cells were same compare to the 80 days section. However, the size of this period is smaller than that of 80 day. Bar: $50 \mu \mathrm{m}$. J. Magnification of epithelium in the area in Fig. 3I. Infiltration of ST4 positive cells were not observed. Bar: 10 $\mu \mathrm{m}$. 
Table 1. Area occupied by T- and B-lymphocytes at the central portion of the vaginal tonsil

\begin{tabular}{|c|c|c|c|c|c|c|c|c|c|c|c|c|c|}
\hline No. & $\begin{array}{l}\text { Age } \\
\text { (day) }\end{array}$ & side & $\begin{array}{l}\mathrm{T} \text { cell } \\
\text { area } \\
\left(\mu \mathrm{m}^{2}\right)\end{array}$ & $\begin{array}{l}\text { B cell } \\
\text { area } \\
\left(\mu \mathrm{m}^{2}\right)\end{array}$ & $\begin{array}{l}\text { total area } \\
\left(\mu \mathrm{m}^{2}\right)\end{array}$ & $\mathrm{T}$ cell $\%$ & B cell \% & side & $\begin{array}{l}\mathrm{T} \text { cell } \\
\text { area } \\
\left(\mu \mathrm{m}^{2}\right)\end{array}$ & $\begin{array}{l}\text { B cell } \\
\text { area } \\
\left(\mu \mathrm{m}^{2}\right)\end{array}$ & $\begin{array}{l}\text { total area } \\
\qquad\left(\mu \mathrm{m}^{2}\right)\end{array}$ & T cell $\%$ & B cell $\%$ \\
\hline 1 & 80 & right & 15888 & 50900 & 66788 & 23.8 & 76.2 & left & 14882 & 49903 & 64785 & 23.0 & 77.0 \\
\hline 2 & 100 & right & 12443 & 88627 & 101070 & 12.3 & 87.7 & left & 10443 & 88258 & 98701 & 10.6 & 89.4 \\
\hline 3 & 120 & right & 14890 & 93470 & 108360 & 13.7 & 86.3 & left & 15756 & 92689 & 108445 & 14.5 & 85.5 \\
\hline 4 & 140 & right & 9768 & 89070 & 98838 & 9.9 & 90.1 & left & 8950 & 92368 & 101318 & 8.8 & 91.2 \\
\hline 5 & 240 & right & 7135 & 41789 & 48924 & 14.6 & 85.4 & left & 6780 & 39809 & 46589 & 14.6 & 85.4 \\
\hline 6 & 300 & right & 7890 & 33570 & 41460 & 19.0 & 81.0 & left & 6794 & 31890 & 38684 & 17.6 & 82.4 \\
\hline 7 & 400 & right & 2379 & 12098 & 14477 & 16.4 & 83.6 & left & 2760 & 13670 & 16430 & 16.8 & 83.2 \\
\hline
\end{tabular}

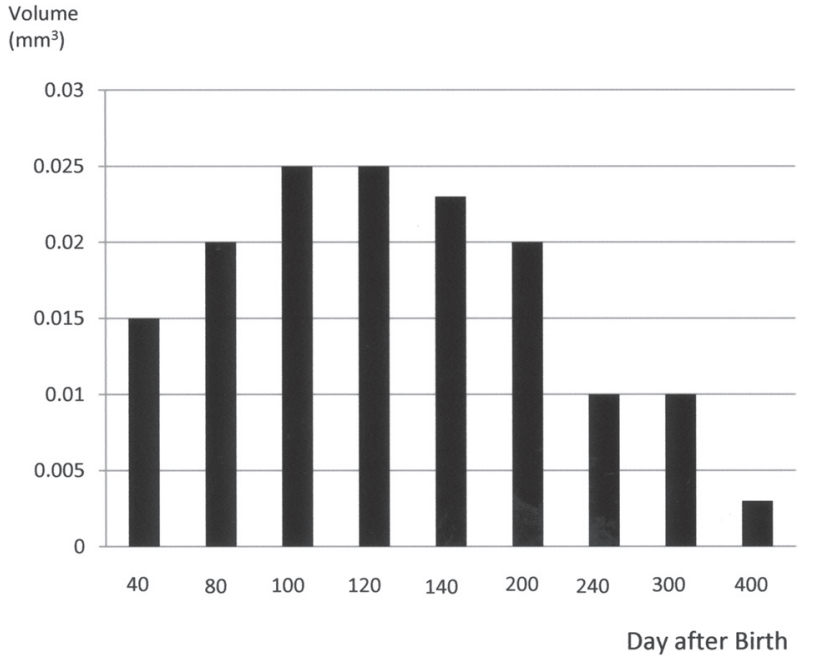

Fig. 5. The volume of vaginal tonsil after birth. The vaginal tonsils appeared around 40 days after birth and increased in size over time, peaking at $0.025 \mathrm{~mm}^{3}$ between $100-120$ days after birth.

of other mammals. The vaginal tonsils of the shrew had a much higher number of $\mathrm{B}$ cells than $\mathrm{T}$ cells. Furthermore, $\mathrm{B}$ cells were present mainly in the parenchyma, where $\mathrm{T}$ cell concentrations were not observed. Boundaries between the follicular, interfollicular and germinal center regions were not clear. The densities and distributions of $\mathrm{T}$ and $\mathrm{B}$ cells in the vaginal tonsils were somewhat similar to those in Peyer's patches (Spencer et al., 1986) and those in the appendix (Spencer, et al., 1985); the Peyers patches, appendix, and the tonsils are each expected to have a germinal center and a deep crypt epithelium with many invading lymphocytes. Along with T cells, B cells were observed in the epithelium of vaginal tonsil. The B cell lineage is the main intraepithelial lymphoid cell component in the crypt of the human palatine tonsils (Tang et al., 1995). The structure and location of these vaginal tonsils may be peculiar because they are primitive lymphatic organs within the laboratory shrew, which is an ancestor of primates (Lin et al., 1985, Ishiguro et al., 1989, Tada et al., 1988).
Typically, tonsils are described as having a well-developed crypt epithelium with immunocyte infiltration and prominent lymph nodules under the capsule (Kimura and Tohya, 1989). Reportedly, a tonsillar structure was seen in the laboratory shrew when compared to the palatine tonsils other mammals (Takagi et al., 1985). Moreover, IgM-positive B cells and antibodies were reportedly distributed in the tonsillar parenchyma (Tohya et al., 1992). The structure of vaginal tonsils was similar to those of previously described mammalian tonsils in that typical lymphoepithelial symbiosis around the vagina and prominent lymph nodules were evident. Due to the fact that the ostium urogenitoanale is used as both a reproductive and an excretory organ, it carries a higher risk of infection and a higher likelihood to be targeted by pathogenic antigens. These vaginal tonsils probably exist to protect these organs from infections.

The size of vaginal tonsils peaks approximately 80 days after birth; they then decrease in size inversely proportional to age. The reproductive period of female laboratory shrews is from 30 to 300 days after birth. The peak or near-peak volume of vaginal tonsils is maintained during this period. The reason why vaginal tonsils exist in the female urogenital system is to protect the reproductive organs from pathogenic antigens that enter the body via the ostium urogenigtoanale. These findings indicate that vaginal tonsil-like structures did not correspond perfectly to the tonsils that have been characterized histologically (Fioretti, 1961), but these structures are probably a primitive type of tonsil in the urogenitoanale.

\section{Acknowledgement}

The authors thank to Dr. Tohya and Dr. Kimura, Kansai University of Health Sciences, Japan for providing the monoclonal antibodies used in this study. This work was supported in part by a grant-in-aid from Fujita Health University, Japan. 


\section{References}

1) Boeker M, Pabst R and Rothkötter HJ. Quantification of B, T and null lymphocyte subpopulations in the blood and lymphoid organs of the pig. Immunobiology 1999; 201:74-87.

2) Brochier J, Samarut C, Bich-thuy LT and Revillard JP. Study of human $\mathrm{T}$ and $\mathrm{B}$ lymphocytes with heterologous antisera. IV. Subpopulation in tonsil and adenoid cell suspensions. Immunol 1978; 25:825-833.

3) Fioretti A. Die Gaumenmandel. Darstellung der Biologie und Physiopathologie. Georg Thieme Verlag, Stuttgart. 1961.

4) Greaves M, Janossy $G$ and Doenhoff $M$. Selective triggering of human T and B lymphocytes in vitro by polyclonal mitogens. J Exp Med 1974; 140:1-18.

5) Hoffmann-Fezer G, Löhre U, Rodt HV and Thierfelders S. Immunohistochemical method III Topographical and quantitative distribution T- and B-cells in human palatine tonsils. Cell Tissue Res 1981; 216:361-375.

6) Ishiguro H, Ichihara $Y$, Namikawa T, Nagatsu $T$ and Kurosawa $Y$. Nucleotide sequence of Suncus murinus immunoglobulin $\mu$ gene and comparison with mouse and human $\mu$ genes. FEBS Lett 1989; 247:317-322.

7) Kimura $M$ and Tohya, K. Scnanning, transmission and immunoelectron microscopial studies of the tonsil-like lymphoid organ of normal and horseradish-peroxidse injected laboratory suncuses. Acta Anat 1989; 136:177-184.

8) Kimura M and Tohya, K and Kuki K. Labaratory Suncus: A new model for tonsil research. Acta Otolaryngol 1996; Sup 523:20-24.

9) Lin SC, Shiga H, Kata Y and Saito H. Serum constituents of Suncus murinus. Exp Anim 1985; 35:77-85.

10) Sakai K, Tanaka A and Isomura G. Developmental study of the anal tonsil in the labaoratory shrew, Suncus murinus. Arch Histol Cytol 2002; 65:97-108.

11) Sakai K and Isomura G. Fine structure of the anal tonsilar epithelium in the laboratory shrew (Suncus murinus). Okajimas Folia Anat Jpn 2004; 81:25-32.

12) Spencer, J., Finn, T. and Isaacson, P.G.; Gut associated lymphoid tissue: a morphological and immunocytochemical study of the human appendix. Gut 1985; 26:672-679.

13) Spencer J, Finn T and Isaacson PG. Human Peyer's patches: an immunohistochemical study. Gut 1986; 27:405-410.

14) Tada $T$ and Obara $Y$. Karyological relationships among four species and subsequences of Sorax revealed by differential staining techniques. J Mamm Soc Japan 1988; 3:21-31.

15) Takagi $T$, Nishikawa $K$, Igarashi $H$ and Nobuki, K. Problems on the definition of a palatine tonsil with special reference to the suncus tonsil. Jap J Tonsil 1985; 24:202-207.

16) Tang $X$, Hori S, Osamura $Y$ and Tsutsumi Y. Reticular crypt epithelium and intra-epithelial lymphoid cells in the lyperplastic human palatine tonsil: An immunohistochemical analysis. Pathology Internaitonal $1995 ;$ 45:34-44

17) Tohya K, Kimura M, Kakudo $K$ and Kawamata J. Immunohistochemical studies on the distribution of lymphocytes in peripheral and mucosal lymphoid tissues of laboratory musk shrews (Suncu murinus). Dev Com Imm 1992; 16:473-483.

18) Tohya $\mathrm{K}$ and Kimura $\mathrm{M}$. Immunohistochemical characterization of B cells and T cells in musk shrew (Suncus murinus) lymphoid tissues using monoclonal antibodies. Histochemistry 1994; 102: $445-450$.

19) Uchida M, Kitagawa $H$, Kikuch, $K$ and Kawaoi A. Immunological study on the human palatine tonsil. Nihon Univ J Med 1983; 25: $175-187$. 